\title{
The price of fast fashion
}

\author{
The fashion industry has changed rapidly in recent years with the increased prevalence of fast fashion, impacting \\ the environment. Efforts to green this polluting industry require action from businesses and consumers.
}

W hen individuals are considering how to minimize their carbon footprint, thoughts often turn to air travel with its large emissions, while some small day-to-day changes may be overlooked. The obvious daily changes that can be made include food choices - such as reducing meat and dairy consumption; personal energy use and supplier; and reduced consumerism.

Fashion is one area in which consumerism has rapidly grown in recent years. Fast fashion has become more prevalent; clothing is produced on shorter timeframes with new designs appearing every few weeks to satisfy demand for the latest trends, but with this comes increased consumption and more waste. It has been estimated that there are 20 new garments manufactured per person each year ${ }^{1}$ and we are buying $60 \%$ more than we were in 2000 . Each garment is worn less before being disposed of and this shorter lifespan means higher relative manufacturing emissions.

Clothing costs have risen slower than those of other consumer goods, increasing their affordability, and there will be continued growth as the middle class expands and purchases increase to match this demographic shift. This combination of factors is expected to result in a tripling of resource consumption by 2050 (compared to 2000).

Textile production is one of the most polluting industries, producing 1.2 billion tonnes of $\mathrm{CO}_{2}$ equivalent $\left(\mathrm{CO}_{2} \mathrm{e}\right)$ per year, which is more emissions than international flights and maritime shipping ${ }^{2}$. Over $60 \%$ of textiles are used in the clothing industry and a large proportions of clothing manufacturing occurs in China and India, countries which rely on coal-fuelled power plants, increasing the footprint of each garment. It has been stated that around 5\% of total global emissions come from the fashion industry ${ }^{3}$.

Emissions from manufacturing depend in part on the material produced. Synthetic fibres have seen rapid production growth since their introduction in the second half of the twentieth century. Polyester is now the most commonly used fabric in clothing, having overtaken cotton early in the twenty-first century. For polyester and other synthetic materials, the emissions for production are much higher as they are produced from fossil fuels such as crude oil. In 2015, production of polyester for textiles use results in more than 706 billion $\mathrm{kg}$ of $\mathrm{CO}_{2} \mathrm{e}$ (ref. ${ }^{4}$ ). The authors of ref. ${ }^{4}$ estimate a single polyester $\mathrm{t}$-shirt has emissions of $5.5 \mathrm{~kg} \mathrm{CO}_{2} \mathrm{e}$, compared with $2.1 \mathrm{~kg} \mathrm{CO}_{2} \mathrm{e}$ for one made from cotton. However cotton is a thirsty crop and its production has greater impacts on land and water.

With limited recycling options to recover reusable fibres, almost $60 \%$ of all clothing produced is disposed of within a year of production (ending in landfill or incineration $)^{5}$. To put that into context, that is one rubbish truck per second to landfill ${ }^{2}$. It has been estimated that less than $1 \%$ of material used to produce clothing is recycled within the clothing industry, with around $13 \%$ recycled for use in other areas ${ }^{2}$.

There are initiatives within the industry to reduce its footprint. One such example is the Fashion Switch (http://go.nature. com/2yhijFU) announced during London Fashion Week 2017, where the British Fashion Council has partnered with designer Vivienne Westwood and the Mayor of London to encourage fashion brands to switch their UK-based interests, that is, their retail stores and offices, to a green-energy supplier or tariff by 2020 .

Recycling of plastics into fabric and clothing is another example of a footprintreducing initiative, with outdoor clothing company Patagonia first making a polyester fleece jacket from recycled bottles in 1993 (http://go.nature.com/2BW3vis). Recycling polyester requires less energy than original production, reducing emissions, and is becoming more common, with use by an increasing number of brands.

There is also a push to return to slow fashion, with higher quality garments with longer product life and utilization. The recent report from the Ellen Macarthur Foundation ${ }^{2}$ advocates for a shift to a circular economy, where the value of products and materials is maintained for as long as possible and waste and resource use is minimised. This, alongside efforts to minimize negative environmental impacts from production, will create a more sustainable industry. For suggestions such as clothing rentals, and increased durability allowing reuse and resale, a shift in

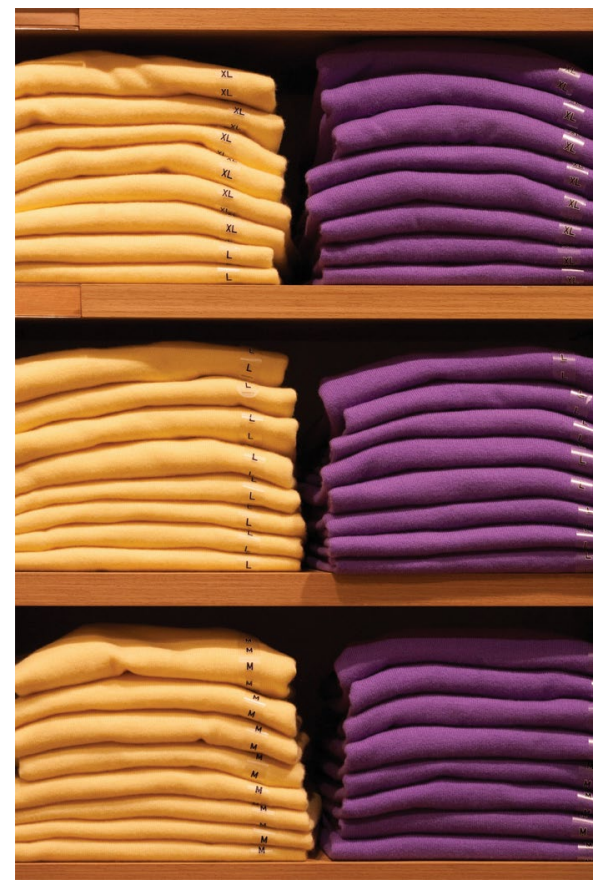

Age Fotostock/Alamy Stock Photo

consumer behaviour and attitude is required for them to gain traction.

Change within the fashion industry needs to happen, and it seems that there is progress. Personal choices have a role in mitigation - there needs to be action at all levels from individuals to big corporations, and from local to international governance, as only by working together and changing behaviours will we see results. However, the individual actions of consumers and businesses can send a strong message and spark change.

Published online: 2 January 2018 https://doi.org/10.1038/s41558-017-0058-9

\footnotetext{
References

1. Drew, D. \& Yehounme, G. The apparel industry's environmental impact in 6 graphics. World Resources Institute (5 July 2017); http://go.nature.com/2jSaZfI

2. A New Textiles Economy: Redesigning Fashion's Future (Ellen MacArthur Foundation, 2017).

3. Bauck, W. The fashion industry emits as much greenhouse gas as all of Russia. Fashionista (22 September 2017); http://go.nature.com/2Cj3ndP

4. Kirchain, R., Olivetti, E., Reed Miller, T. \& Greene, S. Sustainable Apparel Materials (Materials Systems Laboratory, 2015).

5. Remy, N., Speelman, E. \& Swartz, S. Style That's Sustainable: A New Fast-Fashion Formula (McKinsey\&Company, accessed 11 December 2017).
} 